\title{
Transient catchment hydrology after wildfires in a Mediterranean basin: runoff, sediment and woody debris
}

\author{
Renzo Rosso, Maria Cristina Rulli and Daniele Bocchiola \\ Politecnico di Milano, L. Da Vinci Square 32, 20133 Milano, Italy \\ Email for corresponding author: daniele.bocchiola@polimi.it
}

\begin{abstract}
The transient effect of forest fires on runoff, erosion and yield of woody biomass has been investigated by combining the experimental approach with mathematical models of hydrological processes. The case study is the Branega creek in Liguria, Italy, where a forest fire in August 2003 caused substantial changes to soil and vegetation, and left a considerable amount of woody debris on the ground. Immediately after the fire, rainfall simulator experiments in adjacent burned and unburned plots showed the extent to which fire had increased runoff and erosion rates. A distributed hydrological model using the tube-flux approach, calibrated on experimental measurements, has been used to investigate hill slope and channel erosion in a small sub-catchment, 1.5 ha in area, nested in the Branega basin. Simulation runs show that the model accommodates the observed variability of runoff and erosion under disturbed and undisturbed conditions. A model component describing the delivery of wood from hill slopes to the channel in post-fire conditions, validated against local survey data, showed that the removal and transport of woody biomass can be reproduced using an integrated hydrological approach. Hence, transient complexity after wildfires can be addressed by such an approach with empirically determined physically-based parameters.
\end{abstract}

Keywords: forest fires, distributed models, erosion, woody debris

\section{Introduction}

Forest fires have major effects on the hydrology of river catchments. Vegetation is destroyed and a reduction in the resistance of the soil to erosion stimulates Hortonian runoff during subsequent rainstorms (Zierholz, 1997; Prosser, 1997; Booker, 1998; Wilson, 1999, Johansen et al., 2001). Wildfires increase the quantity of sediment produced by the catchment, including soil and woody residue, reduce soil resistance to erosion and increase runoff production (Rulli and Rosso, 2005; Rulli et al., 2006). In the Mediterranean region, where wildfires occur frequently (Naveh, 1975), burning the vegetation increases the presence of shrubs like Cistus (Margaris, 1980) which are invasive and highly inflammable. During a wildfire, organic compounds vaporised in the burning vegetation move through the soil; at a depth characterised by a lower temperature, they condense to form a water-repellent, or hydrophobic soil layer (DeBano, 2000) which can increase runoff production and soil erosion (Dekker et al., 1994; Letey, 2001). The quantity of sediments depends on the lag between the wildfire and the occurrence of heavy rainfall. There is a critical temporal window of one to three growing seasons after the fire, during which the rate of erosion in the modified landscape increases significantly. Generation and transport of woody debris are major issues in the dynamics of the fluvial environment (Keller and Swanson, 1979, Andrus et al., 1988, Abbe and Montgomery, 1996); they interact with fluvial geomorphology and alter erosion and sedimentation patterns (e.g. Murgatroyd and Ternan, 1983; Lienkaemper and Swanson, 1987; Shields and Gippel, 1995; Manga and Kirchner, 2000; Gurnell et al., 2000; Bocchiola et al., 2002, Gomi et al., 2003; Bocchiola et al., 2006b). Transport of woody debris in rivers is dominated mainly by low frequency flood events which sweep away the debris and thus affect the fluvial landscape as well as by river channel conductivity (Jackson and Sturm, 2002; Bocchiola et al., 2006a). The deposition of woody debris during low flows (Haga et al., 2002) and in river discontinuities, such as bends or narrow sections, triggers sediment deposition which yields 'nurse' areas for vegetative colonisation (Fetherston et al., 1995) 
and may initiate the formation of river islands (Gurnell et al., 2000). Thus, woody debris plays a key role in river ecology, by providing a habitat for fish-rearing and housing of riverine species (Jackson and Sturm, 2002) and by affecting water temperatures, water flows and nutrient fluxes (Welty et al., 2002 and references therein). Forest fires increase the production and delivery of woody debris from slopes to streams, by producing new debris (e.g. Benda and Sias, 2003), by the modified soil response to the severe storms which yield most run-off (e.g. Conedera et al., 2003; Robichaud and Hungerford, 2000), by enhanced soil slope erosion (e.g. DeBano, 2000) and by increasing susceptibility to shallow land-slides, which, in turn, interact with woody debris on hill slopes (e.g. Lancaster et al., 2003).

Passage of fire in Mediterranean hill slopes involves complex interactions of surface and soil water, soil sediment and vegetative debris; because the interaction is transient, appropriate field experiments must be designed to explore this complexity. Also, the system must be modelled using a physically-based approach because it would be impossible to collect sufficient data to calibrate conceptual or statistical models. The Branega catchment is representative of the Mediterranean environment and lies a few kilometres from Genoa, in the Liguria region, north-western Italy. In recent years, many wildfires ( 85 fire events between 1975 and 2003) have caused serious damage to people and housing and the landscape in this area has been affected significantly. The transient response of upland catchments to wildfires is, therefore, of great interest in this area, where a large number of small creeks reach the sea across a narrow valley with a high density of population. Hence, a few weeks after the fire, an extensive field campaign evaluated the response of the catchment in terms of the production of sediment and wood. A distributed hydrological model simulated the runoff and erosion processes (Rulli and Rosso, 2005; Rosso et al., 2005 ) in a 1.5-ha drainage basin nested in the Branega river basin. The model comprises a partitioning module (Menduni et al., 2002), a rainfall-runoff module (Vertessy and Elsenbeer, 1999) and an erosion module (Sun et al., 2002). Because the erosion equations have a physical basis, the model has advantages over lumped empirical models. It evaluates, quantitatively, the roles of different factors causing sediment production but mass movements in the form of landslides and debris flows have yet to be included because no such mass movement was observed in the basin during the present campaign. Former experiments on wood entrainment and transport in rivers (Bocchiola et al., 2006a,b) provide semi-empirical relationships to model the initiation of motion, the transport and the distance travelled by woody debris on hill slopes. These consider both dry and wet conditions, whenever overland flow interacts with woody debris. In the dry case, wood moves under gravity and friction; in the wet case, overland flow is the result of hydrodynamic forcing. The presence of obstacles (i.e. other trees or shrubs) must also be addressed. A wood storage model to predict the volume of wood gathered in the channel has been developed as a component of the hydrological model which describes runoff and sediment dynamics. The coupled hydrological and wood models are a comprehensive tool for investigating transient catchment dynamics after forest fires.

\section{Case study}

Plot experiments were effected in the Branega catchment, $4.8 \mathrm{~km}^{2}$ in area, 14 kilometres west of Genoa, in northwestern Italy (Fig. 1). The climate is typically Mediterranean, with wet cool winters and warm dry summers. The area is subject to frequent forest fires ( 85 in the period 1978-2003) and, early in August 2003 after months of extremely hot dry weather with only $105 \mathrm{~mm}$ of rainfall, a large fire occurred.

The average annual rainfall is about $1400 \mathrm{~mm}$; it falls mostly in the autumn, from October to December and in spring, from March to May. Intensity-duration-frequency (IDF) curves show that hourly rainfall with an intensity of $100 \mathrm{~mm} \mathrm{~h}^{-1}$ has a return period of 20 years. Mean annual temperature is around $12^{\circ} \mathrm{C}$. Elevation ranges from sea level to $881 \mathrm{~m}$, with an average of $288 \mathrm{~m}$ a.m.s.l. The mean catchment slope is $52 \%$, with a dominant southerly aspect. Before the August 2003 forest fire, vegetation was mainly a combination of Pinus pinaster A. and shrubs typical of Mediterranean vegetation (Erica arborea L., Erica scoparia L., Arbutus unedo L., etc.). A first-order, ephemeral stream drains a $0.015 \mathrm{~km}^{2}$ catchment where the experimental plots are located (Fig. 1).



Fig. 1. Location of the Branega catchment and experimental plots 


\section{RAINFALL SIMULATION EXPERIMENT}

Experiments using a rainfall simulator assessed the hydrological and sedimentological response to fire forcing. (Rulli et al., 2006). Briefly, two $4 \mathrm{~m}$ by $8 \mathrm{~m}$ plots on the same soil series, slope and vegetation cover were selected, one in a burned and the other in an unburned area nearby (Fig. 1); in each plot runoff and sediment were measured. Both areas had typical Mediterranean vegetation before the fire, which burned all the shrubs and grass off the hill slopes, leaving only the strongest and biggest pine trees and over $90 \%$ bare soil and $10 \%$ burned roots and stones; this compared with less than $20 \%$ bare soil in the unburned plot. The vegetation of the upper part of the control plot was characterised by Erica arborea and Erica scoparia and in the lower part were small pine trees. Six weeks after the forest fire and after only a few millimetres of natural precipitation, the hydrological response of the plots was determined under three different antecedent soil moisture conditions using a rainfall simulator (Panini et al., 1993) to sprinkle a rainfall intensity of $76 \mathrm{~mm} \mathrm{~h}^{-1}$ for one hour. Each plot received three rainfall events: event 1 (hereafter: dry) was conducted with existing soil moisture conditions, event 2 (hereafter: wet) was a few days after event 1 and event 3 (hereafter: very wet) was about two hours after event 2 . Runoff samples, collected every two minutes, were weighed and filtered to determine runoff hydrographs and sediment yield (Rulli et al., 2006). The soil organic matter content and the particle size distribution curve were determined for the cumulative sediment yield. At the end of each event, any sediment remaining in the trough was considered bed load sediment and was collected, dried and weighed. Before and after the experiments, soil samples were weighed and dried to determine the soil moisture conditions.

\section{RESULTS OF THE RAINFALL SIMULATION EXPERIMENTS}

The experimental results (Table 1) showed the difference in the hydrological and erosional response between the burned and unburned plots (Rulli et al., in press). The runoff ratio of the burned plot ranged from 21 to $41 \%$ while, in the unburned plot, it ranged 0.4 to $2 \%$; the runoff ratio from the burned plot was 60 times more than that from the unburned one for the wet run, and 20 times more for the very wet run.

Soil erosion differed markedly between the burned and unburned plots. At the burned site, the average erosion rate (the total sediment yield per unit area and per hour), was $16 \mathrm{~g} \mathrm{~m}^{-2} \mathrm{~h}^{-1}$ during the first two simulations and twice as much during the third. By comparison, the unburned plot yielded only $0.11 \mathrm{~g} \mathrm{~m}^{-2} \mathrm{~h}^{-1}$ of sediments in the wet simulation and $0.23 \mathrm{~g} \mathrm{~m}^{-2} \mathrm{~h}^{-1}$ in the very wet one. Therefore, on average, the total sediment produced by the burned plot was two orders of magnitude higher than that from the control plot (for comparison, see Wilson, 1999; Johansen et al., 2001). The reasons for the increase in sediment yield are manifold. The vegetation and litter in the unburned site limited the fraction of the soil area affected by rainfall splash and the resultant detachment of soil by overland flow. At the burnt site, the high runoff rate increased the sediment transport capacity of overland flow. Eventually, sediment production would be influenced by any difference in soil texture; the soil of the burnt plot was finer because of its larger percentage of clay and silt as well as of ash and charcoal following the wildfire. The concentration of sediment in the runoff, a relative measure of soil erodibility, was similar for all the events at the burned site, around one gramme per litre, and two or three times less in the unburned area. The amount of sediment eroded from the burnt soil was greater, not only because of the higher runoff rate but also due to the fire-induced soil degradation and sediment mobilisation from rainfall and overland flow.

\section{Field surveys of woody debris}

A field survey of woody relics was made over the whole of the experimental 1.5 ha catchment at the same time as the rainfall simulation experiment and before any further significant storm event occurred. The forested area on the

Table 1. Summary of the results of rainfall simulation. Bu is burned, Un is unburned

\begin{tabular}{lcccccc}
\hline & $B u$ & $B u$ & $B u$ & Un & Un & Un \\
\hline Event & 1 & 2 & 3 & 1 & 2 & 3 \\
Plot area $\left(\mathrm{m}^{2}\right)$ & 13 & 26 & 26 & 30 & 30 & 30 \\
Average intensity $\left(\mathrm{mm} \mathrm{h}^{-1}\right)$ & 74 & 68 & 76 & 58 & 74 & 74 \\
Duration (min) & 60 & 55 & 60 & 42 & 61 & 71 \\
Runoff ratio & 0.21 & 0.24 & 0.41 & 0 & 0.004 & 0.02 \\
Peak runoff $\left(\mathrm{mm} \mathrm{h}^{-1}\right)$ & 33.5 & 25.3 & 41.3 & 0 & 0.7 & 2.2 \\
Average erosion rate $\left(\mathrm{g} \mathrm{m}^{-2} \mathrm{~h}^{-1}\right)$ & 16.8 & 17.8 & 32.9 & 0 & 0.1 & 0.2 \\
\hline
\end{tabular}


observed site is entirely sea pine (Pinus pinaster), typical of the Liguria region. In the burned area, practically all the trees lost all their canopy and many of their branches. On the ground, woody debris, mainly cylindrical pieces with no roots or canopy, were measured to determine their distribution in terms of length, $L_{\text {log }}$, diameter $D_{\log }$ and orientation (perpendicular or parallel to stream, or to the site slope). The research was limited to the large woody debris (LWD), i.e. those with length $L_{\log }>1 \mathrm{~m}$ or with diameter, $D_{\log }>0.1 \mathrm{~m}$ (e.g. Braudrick and Grant, 2001; Bocchiola et al., 2006a,b). This is because it is difficult to map and to track the position of the small fine woody debris (S-FWD, with $D_{\log }<0.1 \mathrm{~m}$ and $L_{\log }<1 \mathrm{~m}$ ), because of the considerable amount of such debris and the possibility of it disintegrating over time or breaking during rainfall events, thus possibly disappearing or being unidentifiable. However, this woody residue is taken into account in the model, as explained later. The mass density of the $\operatorname{logs} \rho_{\log }$ has been estimated. The main features of the observed distribution of pieces of wood are shown in Table 2. Also, the distribution in space of the trees has been determined to be used in the wood module (see below). The pieces of LWD observed (64 pieces) were labelled and their coordinates taken by portable GPS to track their position in case of further movement. Also, several pictures were taken for comparison. In some sample plots in the burned area, the spatial densities of standing trees before and after the fire, Dens ${ }_{u}$ and Dens have been evaluated, giving an estimate of the probability of the trees falling during a fire event, $P_{\text {fall }}$. The density of trees before the fire has been estimated from cross-checking high resolution satellite imagery (using a pre-fire

Table 2. Main properties of the observed woody relics from LWD ( $D_{\log }>0.1$ or $\left.L_{\log }>1 \mathrm{~m}\right)$. E[] is expected, or sample average value, MAX[] is highest value observed and CV[] is sample coefficient of variation.

\begin{tabular}{|c|c|c|c|}
\hline Wood & Downed wood & Trunks & Standing \\
\hline $\mathrm{E}\left[\rho_{\log }\right]\left[\mathrm{kg} \mathrm{m}^{-3}\right]$ & 626 & $\begin{array}{l}\text { Dens }_{b} \\
{\text { [trees } \mathrm{m}^{-2} \text { ] }}\end{array}$ & 0.04 \\
\hline $\mathrm{CV}\left[\rho_{\text {log }}\right]\left[\mathrm{kg} \mathrm{m}^{-3}\right][]$. & 0.20 & $P_{\text {fall }}[]$. & 0.26 \\
\hline $\mathrm{E}\left[D_{\log }\right][\mathrm{m}]$ & 0.10 & $D B H_{a v}[\mathrm{~m}]$ & 0.19 \\
\hline $\operatorname{MAX}\left[D_{l o g}\right][\mathrm{m}]$ & 0.22 & $L_{0}[\mathrm{~m}]$ & 4.94 \\
\hline $\mathrm{CV}\left[D_{\log }\right][]$. & 0.39 & $H_{\text {tree }}[\mathrm{m}]$ & 13.5 \\
\hline $\mathrm{E}\left[L_{l o g}\right][\mathrm{m}]$ & 3.25 & $C_{\text {comb }}[]$. & 0.86 \\
\hline $\operatorname{MAX}\left[L_{l o g}\right][\mathrm{m}]$ & 8.10 & $\Phi_{\mathrm{R}}\left[^{\circ}\right]$ & 25 \\
\hline $\mathrm{CV}\left[L_{\text {log }}\right][]$. & 0.64 & $W_{c h}\left[\mathrm{~m}^{3}\right]$ & 1.18 \\
\hline Parallel [.] & 0.33 & $W_{d c}\left[\mathrm{~m}^{3}\right]$ & 0.69 \\
\hline Perpendicular [.] & 0.67 & $W_{d}\left[\mathrm{~m}^{3}\right]$ & 0.49 \\
\hline Dens $_{u}\left[\right.$ trees $\left./ \mathrm{m}^{2}\right]$ & 0.06 & $W_{f w}\left[\mathrm{~m}^{3}\right]$ & $3.5 * 10^{-3}$ \\
\hline
\end{tabular}

QuickBird ${ }^{\circledR}$ image, resolution $0.7 \mathrm{~m}$ on the ground in panchromatic) and local survey of the standing trees and roots holes of fallen trees.

The average value of the diameter at breast height, $D B H_{a v}$, $(1.37 \mathrm{~m})$ of the trunks was evaluated for the wood transport module. Also, the average nearest neighbour distance between the standing trees was measured as $L_{0}=4.94 \mathrm{~m}$, for the wood module. From the type and age of the trees present in the area (Pinus pinaster), the dominant tree height $H_{\text {tree }}$ was calculated from the literature and from field surveys with botanical specialists. By comparing the observed volume of the woody residue on the ground and the expected volume of the fallen trees, deduced from the average geometry of the trunks, a coefficient of combustion due to fire, $C_{\text {comb }}$ was evaluated (Table 2). The total amount of wood biomass $\left(\mathrm{m}^{3} W_{c h}\right)$ conveyed in the channel was estimated by measuring the logs observed in the channel. A reasonable estimate of the amount of wood was made from direct contributions to the channel $W_{d c}$ also reported in Table 2. This was done by qualitative observation of the position of the individual pieces of wood. Usually, wood pieces from direct contribution are placed perpendicular to the channel, sometimes bridging over it, leaning on one or on both the channel's edges. Also, in some cases, in the surroundings of the channel, the root hole of a former standing tree was found, together with the remains of the tree itself, in the channel. Because no relevant storm event was observed prior to the field survey of woody debris, it is reasonably assumed that the debris volume $W_{c h}$ is entirely due to dry transport, including the debris from direct contribution $W_{d c}$ and the debris from dry transport on hill slopes, $W_{d}=W_{c h}-W_{d c}$.

Three months after the fire, at the time of the sediment yield survey, the distribution of the woody debris in the channel was measured. Again, the research was limited to the LWD. The C-LWD and F-LWD that were labelled during the field survey were found to be in the same position, as verified by the portable GPS and by comparison with the pictures taken during the first survey. Thus, no relevant transport of LWD had occurred. As explained above, the amount of the S-FWD could not be evaluated but it is more likely to move during storm events. Hence, the presence of S-FWD was investigated in the sediment captured at the channel outlet at the weir. The volume of the S-FWD therein was $W_{f w}=3.5 * 10^{-3} \mathrm{~m}^{3}$ (i.e. 3.5 litres). While it is impossible to trace the origin of this debris, which may be due, for instance, to dry transport occurring after the fire, it is supposed that the dry transport of wood is confined to the period immediately after the fire, while the transport of the volume $W_{f w}$ is due to the storm events which occurred during the subsequent three-month period. 


\section{Modelling transient hydrology after forest fires}

\section{RUNOFF AND EROSION}

\section{Model overview}

The field experiments on the burned plot have been reproduced through a distributed erosion and sedimentation model, (AUGUSTO-NERONE model: Rulli et al., 2005). The parameters used in these simulations are adopted, successively, to investigate fire effects on soil erosion at a larger scale. In fact, the model was applied to the small (1.5ha) sub-basin of the Branega catchment, where the burned plot was located. An in-stream weir at the outlet of the catchment measured the sediment from the recently burned area. Three months after the fire, the accumulated sediments upstream of the weir were collected and weighed about 2000 $\mathrm{kg}$. During this 98-day period, there were several intense rainfall events, amounting to a total fall of $1037 \mathrm{~mm}$.

The AUGUSTO-NERONE model combines well known components for each process considered. It comprises: (a) a catchment partitioning module; (b) a rainfall-runoff module; and (c) an erosion and sedimentation module. Catchment partitioning is based on the 'tube-flux' approach procedure (Onstad and Brakensiek, 1968) as developed by Menduni et al. (2000), i.e. using the drainage path as the framework for contour-based catchment modelling. This approach can provide an accurate description of terrain morphology, governing surface and subsurface fluxes. The procedure developed by Menduni et al. (2000) is based on a preliminary identification of an Ideal Drainage Network (IDN) based on contour lines through a variable mesh size, from which the Actual Drainage Network (ADN) is extracted, using land morphology. The model first derives the steepest slope lines from the highest contour and then proceeds down slope. Once the extraction of the ideal drainage network is complete, the model identifies all the contributing areas draining to each link (sub-basin). The automatic drainage network delineation is straightforward, and the method provides physically consistent onedimensional stream channels. Further, the procedure defines polygons bounded by the two steepest adjacent contour lines, orthogonal to the contour lines. Overland flow is routed through stream tubes, formed by pairs of stream lines normal to the contour lines (equipotentials) of the catchment (Onstad and Brekensiek, 1968). The model also identifies, automatically, significant terrain characteristics (e.g. peaks and saddles) and accounts for their effect on streamflow. Using this type of discretisation, the model divides the elements where the water flows into (i) cells, i.e. polygons where the overland flow is modelled as sheet flow and (ii) channels, obtained by joining two or more stream tubes where surface runoff is channelled. This partitioning procedure makes it possible to solve the equations that describe the active hydrological processes in a monodimensional way.

Storm-flow is modelled by the Soil Bucket Model (SBM; Vertessy and Elsenbeer, 1999) in the contour elements of the catchment partitioning described above (see Rulli et al., 2005). This module consists of (1) contour-based element network based on catchment partitioning, (2) a simple bucket model for handling soil water fluxes in each element, (3) a one-dimensional kinematic sub-surface flow module to simulate the movement of soil water down slope along the 'stream tubes' and (4) a one-dimensional kinematic wave overland flow model for simulating surface runoff along the stream tubes. For each time step and each element, the model computes water table depth, soil moisture storage, lateral subsurface flow and overland flow depth, velocity and discharge. Three overland flow processes are considered, i.e. (a) infiltration excess, (b) saturation excess and (c) ex-filtration of upstream sub-surface flow. The choice of the SBM model was first dictated by the data set available. Unfortunately, some of the field data necessary to use a more sophisticated model are lacking (e.g. water fluxes observation). The SBM is simple but capable of capturing the essence of the process being investigated. The computed hydrological fluxes are then used to feed the erosion module.

The amount of sediment eroded and deposited is computed following the approach proposed by Sun et al. (2002). The model calculates, for each element and time step, the amount of sediment mobilised by raindrop splash in inter-rill areas and by overland flow in channels. Inter-rill area detachment is calculated as a function of rainfall intensity, the USLE soil erodibility factor, the USLE cover and management factor and a slope factor (Foster, 1982). Rill detachment is computed as a simple function of discharge, the slope of the channel and a calibration parameter $\alpha$ (Foster, 1982). Then, the transport capacity of overland flow is computed and used to determine the actual erosion or deposition rate.

\section{Plot-scale simulations}

Plot scale simulations aim to reproduce, using a distributed model, the hydrological and sedimentological response of the burned plot as observed during the field experiments described above. For this purpose, two rainfall simulation events (events 2 and 3 ) were modelled for the burned plot, after collecting the required model input parameters from field data and surveys. In particular, an accurate topographic survey provided a high resolution elevation model of the study plot (20 cm spatial resolution). Three soil samples (P1, P2 and P3) were collected throughout the studied basin 
to determine soil depth, particle-size distribution and organic matter content. Soil porosity and residual moisture content, obtained from values in the literature for the local soil type, were set to 0.4 and 0.1 , respectively (Clapp and Hornberger, 1978). The saturated hydraulic conductivity was measured at different locations around the plot using a Guelph permeameter; the mean value, around $57 \mathrm{~mm} \mathrm{~h}^{-1}$, was used in the model simulations at the plot scale. The Manning roughness coefficients were set to 0.02 for slope elements, because little ground cover remained after the fire, while its values for the channel elements ranged from 0.011 to 0.065 . To model the erosion processes based on the equations proposed by Sun et al. (2002), four more parameters had to be estimated: (a) the median grain size of the sediment; (b) and (c) the USLE parameters $K$ and $C_{s l r}$, respectively the soil erodibility factor and the cover and management factor; and (d) one calibration parameter $\alpha$, used in the computation of soil detachment in channel elements. The USLE soil erodibility factor was estimated using the regression equation proposed by Wischmeier and Smith (1978), which depends on four parameters: (i) a texture factor $(M)$; (ii) the percent organic matter $(a)$; (iii) a soil structure code $(b)$; and (iv) a soil permeability class (c). The first two parameters ( $M$ and $a$ ) were evaluated from actual soil sample analyses, whereas the permeability class was estimated from in situ measurements of hydraulic conductivity; the soil structure code was estimated in the field. The resulting soil erodibility factor was $0.024 \mathrm{~kg} \mathrm{~h}^{-1} \mathrm{~N}^{-1} \mathrm{~m}^{-2}$. The cover and management factor, representing an estimate of the ratio of soil loss under actual conditions to losses experienced under continuous fallow, was set to 1 , because the recently burned area was essentially devoid of vegetation and hence susceptible to the type of soil losses associated with fallow soil. In fact, in the study area, ground cover was less than 5\% due to rock fragments and plant residues, canopy cover was around $20 \%$, and the organic matter content was substantially reduced by the fire. The median grain size of the soil, based on several soil sample analyses, was $0.12 \mathrm{~mm}$. The soil moisture content measured before each rainfall event simulation, was used as the initial soil condition.

Before the rainfall experiments, four soil samples were collected in each plot at different depths to determine antecedent moisture conditions; these were determined gravimetrically after drying. Eventually, the same rainfall intensities as those simulated by the sprinkler $\left(68 \mathrm{~mm} \mathrm{~h}^{-1}\right.$ for Event 2 and $76 \mathrm{~mm} \mathrm{~h}^{-1}$ for Event 3) were given as input to the AUGUSTO-NERONE model, using a computational time step of $1 \mathrm{~s}$. The model performance was assessed by comparing its results with the runoff hydrographs and sedigraphs calculated during the sprinkler rainfall simulation experiments (Fig. 2). The total discharge was simulated with reasonable accuracy in both events, although the model predicted higher peak runoff, especially during Event 2 (i.e. wet event on burned plot). The shape of the hydrographs and the start time for runoff were reproduced satisfactorily but the simulated rising limbs of the hydrographs were slower than those observed. This may have been due to the use of a spatially uniform value for the saturated conductivity of the soil, unable to simulate the quick runoff production of the less permeable parts of the plot. For both events, the
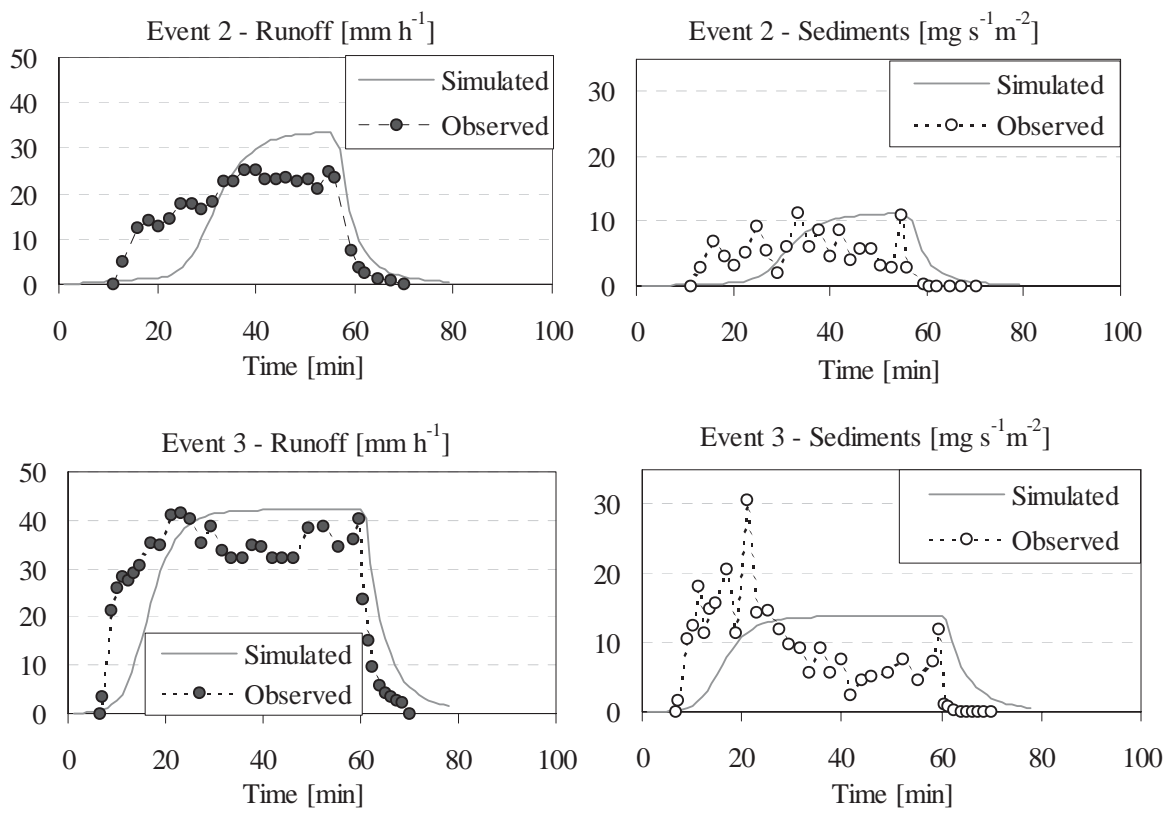

Fig.2. Comparison between observed and simulated hydrographs and sedigraphs for events 2 (wet) and 3 (very wet) on the burned plot. 
steady-state runoff was reached at the same time in the model simulations and field experiments: in Event 2 (wet) it was at the end of the simulation, whereas in Event 3 (even wetter) stable conditions were achieved only a few minutes after the initiation of runoff. The simulated sedigraphs agreed with those obtained from observations, in terms of the total amount of soil loss, but the observed patterns were more irregular than the simulated ones. Also, the onset of sediment delivery was correctly simulated; however, the simulated rising and falling limbs of the sedigraphs were less steep than in the field experiments. Overall, despite some differences, the model was able to reproduce, with a good degree of accuracy, the processes observed in the field.

\section{Basin-scale simulations}

The distributed model was applied at the basin scale for the 1.5 ha sub-basin (hereafter SBB) of the Branega creek, within which the experimental burned plot is nested. As model input, 98 days of rainfall events were retrieved for three rain gauges, positioned outside the basin and rescaled to the SBB area by Thiessen polygons. A DEM with 5-m plane resolution was used for basin partitioning. The SBB was partitioned into 217 elements of which 30 were considered channel elements. The average area of the elements was $78 \mathrm{~m}^{2}$. For the SBB simulations, the same parameters as for the plot scale simulation were used, except for soil depth and hydraulic conductivity, which were assumed to vary spatially. Based on the field surveys and ad hoc measurements, the former ranged from 0.35 to $1.1 \mathrm{~m}$, and the latter from 20 to $140 \mathrm{~mm} \mathrm{~h}^{-1}$. The parameter $\alpha$ was used as a calibration parameter, whereas the erosion equation parameters were set to the same values used in the plot scale simulations. The computational time step was set at $100 \mathrm{~s}$, and rainfall input was determined from three rain gauge stations close to the basin that recorded rainfall at 5-min intervals. Nine rainfall events, representing $90 \%$ of the total accumulated rainfall, were selected and the resulting hydrological and erosion/deposition response simulated. Then, the total amount of sediment simulated by the model was compared with actual erosion measurements in the field. The results of sub-basin scale simulations could be compared with observations only in terms of accumulated sediment yields, because time continuous water and sediment discharge data are not available. The model estimated the sediment yield of the small catchment after the nine major events as $2600 \mathrm{~kg}$, compared to a measured value of $2000 \mathrm{~kg}$. The simulated model runs incorporated a wide range of the average rainfall intensities, ranging from 3 to $77 \mathrm{~mm} \mathrm{~h}^{-1}$. Even during several weak rainfall events, the small amount of rainfall detachment did not limit the erosion process on the hill slopes, because the limiting factor remained the transport capacity. $K$ and $C_{s l r}$ (the soil erodibility factor and the cover and management factor, respectively) played leading roles in the availability of erodible soil for post-fire conditions, at least at these spatial scales. It was concluded that the model provided acceptable results in driving the transition from the plot to the catchment scale, the latter being more useful for developing appropriate post-fire catchment rehabilitation plans.

\section{Wood yield}

To evaluate the yield of woody debris in the main channel of the 1.5 ha sub-basin, a wood budget module was developed by assuming simple rules for wood entrainment, motion triggering and transport, deduced from a set of flume experiments carried out by the authors (Bocchiola et al., in press a,b).

\section{FLUME EXPERIMENTS ON WOOD ENTRAINMENT}

\section{AND TRANSPORT}

Experiments with cylindrical pieces of wood were made in a $30 \mathrm{~m}$ long, $1 \mathrm{~m}$ wide laboratory flume using hand-made wooden dowels of known properties to reproduce the situation of woody debris from fallen trees or conveyed for some distance inside the channel. Wood entrainment is considered first (e.g. Braudrick and Grant, 2000) with depth and velocity thresholds deduced which trigger wood motion. The transport of wood in a complex environment is then addressed (e.g. Braudrick and Grant, 2001). The patterns of motion and the stopping probability of wood dowels in running water is observed by placing vertical rods to obstruct the motion (Bocchiola et al., 2006b). The triggering of the motion of wood pieces in rivers is complex (e.g. Braudrick and Grant, 2000; Haga et al., 2002) so, to provide the simplest possible solution for implementing the wood module, the rule is adopted as from Bocchiola et al., 2006b. This provides thresholds for initiation of motion of handmade dowels positioned both parallel and perpendicular to the flow; these initiate motion either by sliding or by rolling on the bed. The equilibrium equation can be given in a simple dimensionless form as

$$
Y^{*}=\frac{1.26}{1+2.49 X_{S, R}^{*}},
$$

where the subscript $S, R$, indicates the situation of sliding and rolling, respectively. The variable $Y^{*}$ is defined as

$$
Y^{*}=\frac{\rho_{w} d_{w}}{\rho_{\log } D_{\log }},
$$

in both cases of sliding and rolling. The variable $d_{w}$ indicates 
the depth of water (with density $\rho_{w}$ ) necessary to move a $\log$ with diameter $D_{\log }$ and mass density $\rho_{\log }$ and refers to undisturbed flow conditions (see Braudrick and Grant, 2000). The definition of $X^{*}$ depends on the type of motion as

$$
X_{S}^{*}=\frac{1}{2} \frac{U_{w}^{2}}{g L_{\log }} \frac{1}{\left(\cos \alpha \tan \Phi_{S}-\sin \alpha\right)},
$$

for sliding, where $\alpha$ is the bed slope, $U_{w}$ is the water velocity in the absence of the $\log , L_{\log }$ is the log length and $\Phi_{S}$ is the friction angle of the dowels on the channel bed. For the case of rolling $X^{*}$ is

$$
X_{R}^{*}=\frac{1}{2} \frac{U_{w}^{2}}{g D_{\log }} \frac{1}{\left(\cos \alpha \tan \Phi_{R}-\sin \alpha\right)},
$$

where $\Phi_{R}$ is friction angle at rolling (i.e. the angle at which rolling occurs under simple gravity). The proper scaling of the variables in Eqn. (1) and the range of validity of the latter is described in Bocchiola et al., 2006a, b. The value of the intercept for $X^{*}=0$, i.e. for very low flow velocity, is $Y^{*}=1.26$, representing the 'flotation threshold' (see also Haga et al., 2002). The multiplier for $Y^{*}$ in Eqn. (1) is an estimate of the average drag coefficient exerted by the water flow on the $\log$ and it is valid in a given range of flow conditions (Manga and Kirchner, 2000; Hygelund and Manga, 2003; Bocchiola et al., in press a). Also, some burned pieces of wood (average $L_{\text {log }}=0.251 \mathrm{~m}$, average $D_{\log }=0.047 \mathrm{~m}$ ) were retrieved in the investigated area and tested for stability during the flume experiments; they fitted the experimental data obtained with handmade dowels (not shown here for brevity, see Bocchiola et al., 2004). It is, therefore, assumed that the entrainment rules given here are also valid for burned logs in the post-fire environment in the basin considered. As far as wood transport is concerned, the distance travelled $L_{T}$ is shown to be a function of the average nearest neighbour distance between obstacles $L_{0}$ (set to $0.26 \mathrm{~m}$ in the experiment) of the dowel's length $L_{\log }$ and of the force applied by the flow. Three dimensionless groups are introduced (see Bocchiola et al., 2006b). The first is the standardised distance travelled, $L^{*}=L_{T} / L_{0}$, while the second is the 'obstruction ratio' $L_{L}^{*}=L_{\text {Log }} / L_{0}$. The third group is the excess of force with respect to the critical equilibrium condition. Unless flotation occurs $\left(Y^{*}<1.26\right)$, the dowels move only by rolling (as in Bocchiola et al., 2006b, Fig. 1). Therefore, the excess of forcing for wet conditions is given as being above the stability threshold for incipient motion at rolling.

$$
X_{e w}^{*}=X_{R}^{*}-X_{c}^{*}=X_{R}^{*}-\left(\frac{1.26}{Y^{*}}-1\right) / 2.49 \quad Y^{*} \leq 1.26
$$
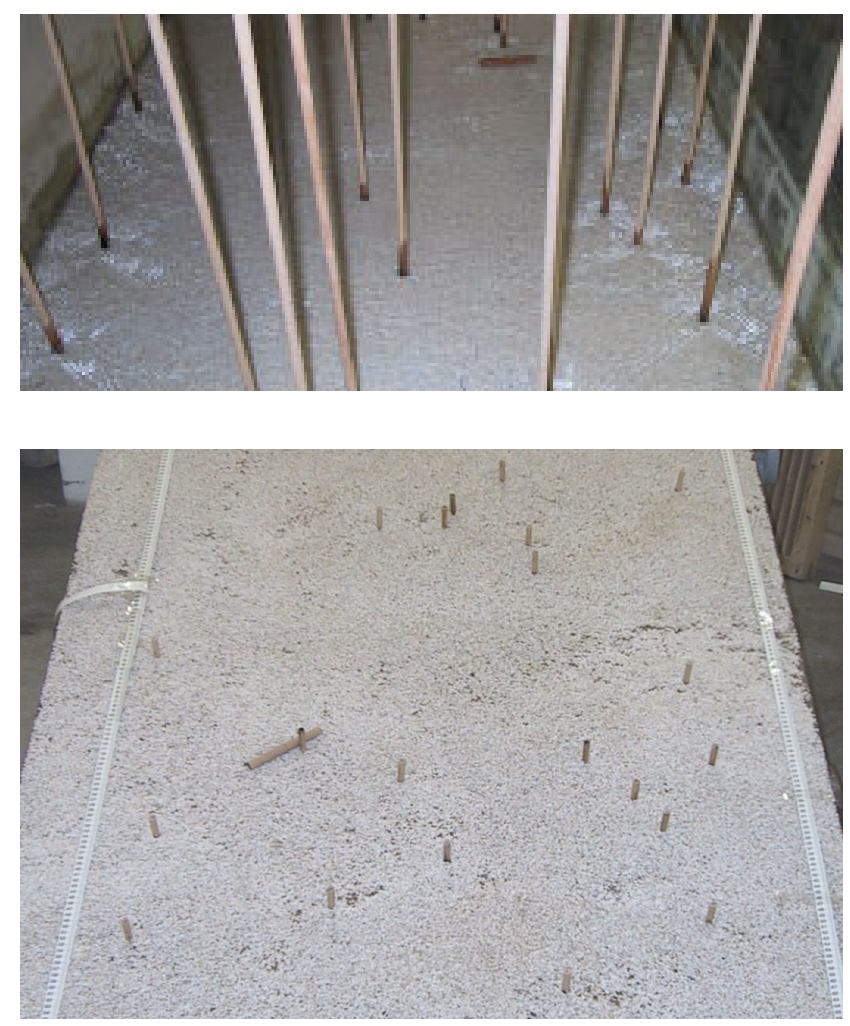

Fig. 3. Wood motion experiments: wet conditions (top), dry conditions (below).

The case of rolling is of interest because the motion of wood on hill slopes in the presence of overland flow can be described according to the approach given here.

The wood motion experiments were also carried out for dry environment (Fig. 3b), to provide rules for wood motion on hill slopes or in channels when no water is present. Particularly, in this case, the force balance on the dowels is provided by the action of gravity and friction. Eqn. (1) for incipient motion is modified accordingly by equating the slope angle to the friction angle, as $\alpha=\Phi_{\mathrm{S}, \mathrm{R}}$, for sliding and rolling, respectively, stating that the wood moves as and when the local slope is equal to the friction angle. According to the observation that logs move mainly by rolling in dry conditions, the dimensionless excess of forcing $X_{e d}$ is given by adding the ratio of the tangent of the slope angle to that of the friction angle

$$
X_{e d}^{*}=\tan \alpha / \tan \Phi_{R}
$$

Probabilistic assessment of the distance travelled by the wood pieces

It is possible to interpret the results from the wood motion 
experiments as showing that the dimensionless distance $L_{T}{ }^{*}$ travelled by a dowel of dimensionless length $L_{L}{ }^{*}$ is a random variable, the probability distribution of which depends on $L_{L}{ }^{*}$ and $X_{e}^{*}$ as

$$
F_{L_{L}{ }^{*}}\left(L_{T}^{* \prime}\right)=\operatorname{Pr}\left(L_{T}^{*} \leq L_{T}^{* \prime}\right)=F_{L_{L}^{*}}\left(L_{T}^{*} \mid X_{e}^{*}\right)
$$

The frequency distribution of the distance travelled by the dowels is evaluated for different values of $L_{L}{ }^{*}$ and $X_{e}{ }^{*}$ (Bocchiola et al., 2006b, Figs. 5,6 and 7). The observed frequencies are reported in Fig. 4 (Weibull plotting position) of the distances travelled for the set of experiments regarding the rolling dowels ( $L_{\text {log }}$ from $0.05 \mathrm{~m}$ to $0.15 \mathrm{~m}$ ) in the wet environment, together with the dowels ( $L_{l o g}$ from $0.05 \mathrm{~m}$ to $0.25 \mathrm{~m}$ ) in the dry environment, made dimensionless with respect to their sample average, namely $L^{\prime}=L_{T} / L_{a v}$. The dry and wet cases were combined because the two sample frequency distributions were similar in shape. Also, the tentative accommodation of the frequencies observed for the two cases of wet and dry transport gave virtually equivalent results to the tentative accommodation of the frequencies obtained for the whole (i.e. wet plus dry) sample. The authors tentatively accommodated the observed frequencies with some standard distributions, namely the



Fig. 4. Fit of the observed frequencies of the distances travelled by the dowels at rolling, made dimensionless with respect to their sample average.
Normal distribution NR, Lognormal distribution LN, Gamma distribution GA and Exponential distribution, EX (not shown for brevity). The best fit is given by the LN distribution, as

$$
F_{L^{\prime}}=L N\left(\mu_{\ln L^{\prime}} ; \sigma_{\ln L^{\prime}}\right)=L N(-0.14 ; 0.52)
$$

Equation (8) is shown in Fig. 4, together with the Kolmogorov-Smirnov boundaries $(\alpha=0.01)$. Although some scatter of the dots is observed, the sample distances made dimensionless with respect to their average seem to be reasonably distributed according to Eqn. (8).

In turn, the average dimensionless travelled distance $L_{a v}^{*}=L_{a v} / L_{0}$ depends on the dimensionless dowel lengths, $L_{L}^{*}$ and on the excess of forcing, $X_{e}^{*}$ (see Bocchiola et al., in press b), as

$$
L_{T, a v}=L_{T, a v}\left(L_{L}^{*}, X_{e}^{*}\right)=a+b \cdot L_{L}^{*}+c \cdot X_{e w, d}^{*},
$$

with $a=1.94, b=-1.58$ and $c=0.96$ (see Table 3 ) and is valid for both wet and dry conditions. Again, no significant difference was seen between the goodness of fit in Eqn. (9) by considering the wet and dry cases separately and, therefore, the same equation was used for both.

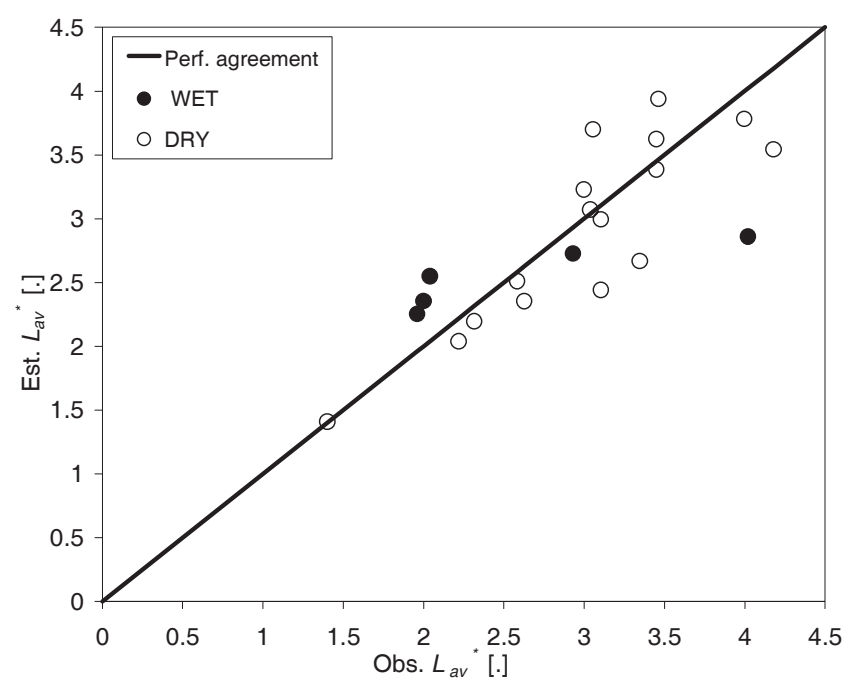

Fig. 5. Average travel distance, wet case and dry case.

Table 3. Fitting of Eqn. (9)

\begin{tabular}{lccccc}
\hline & Value & Std dev. & Student's $t$ p-value & Lower 95\% & Upper 95\% \\
\hline Intercept & 1.94 & 0.07 & $10^{-4}$ & 1.79 & 2.08 \\
$X_{e}$ & 0.96 & 0.04 & $10^{-4}$ & 0.88 & 1.04 \\
$L^{*}$ & -1.58 & 0.07 & $10^{-4}$ & -1.73 & -1.43 \\
\hline
\end{tabular}




\section{WOOD BUDGET MODULE}

A wood budget module is developed here to model the transport of wood on the hill slopes towards the channel. In the present case the aim is to model the transport of wood immediately after the forest fire in dry conditions (i.e. essentially due to gravity) forced by the occurrence of runoff. The model does not account for the many complex phenomena governing the transport of wood on hill slopes, but provides a simple scheme which captures the essence of the problem and provides a reasonable assessment of the wood budget in forest fire forcing conditions.

The wood budget module considers the delivery of woody debris to the channel in both dry and wet conditions and is built as follows (see also Welty et al., 2002 for an explanation of some of the wood module assumptions). For each element of the basin partition the wood module takes in input the hydrological fluxes given by the hydrological module. The downfallen woody debris (DWD) is schematised as comprising cylindrical pieces of wood, with no roots or canopy, as observed in the field survey after the fire. It is further assumed that the wood falls down during or soon after the fire due to the fire, or to external forcing by wind, vibrations or the action of animals.

It is assumed that each piece of wood behaves independently of the others. The hypothesis is that the wood that falls on the hill slopes moves towards the channel by rolling with its axis perpendicular to the steepest slope direction. The momentum acquired by the DWD during the fall is neglected and the model is only fed with the distribution of the wood relics on the ground. The transport of wood due to shallow landslides or debris flow (e.g. Lancaster et al., 2003) has been neglected so far.

The hypothesis is that the DWD moves when there is sufficient force to initiate motion and stops when that forcing is no longer sufficient because of dissipation of the kinetic energy of the DWD, or an obstacle stops the DWD (with a probability $F_{L}$, as in Eqns. 8 and 9), or it reaches the main channel, where it stops. The obstacles to motion in the module are provided by the standing trees, the nearest neighbour distance $L_{0}$ of which is set to $4.94 \mathrm{~m}$ (Table 2).

The DWD on the ground is divided into six different diameter classes, based on the probability of occurrence observed from field measurements and the average log diameter is taken as representative for the calculation (resulting in $D_{\text {log }}=0.03 \mathrm{~m}, 0.05 \mathrm{~m}, 0.07 \mathrm{~m}, 0.09 \mathrm{~m}, 0.11 \mathrm{~m}$ and $0.14 \mathrm{~m}$ ). For each class, the average length is estimated from the data and used to calculate the expected volume of the woody debris (resulting in $L_{l o g}=0.5 \mathrm{~m}, 1.99 \mathrm{~m}, 2.58 \mathrm{~m}$, $2.66 \mathrm{~m}, 3.33 \mathrm{~m}$ and $3.49 \mathrm{~m}$, respectively). According to the qualitative classification scheme adopted by Braudrick and
Grant (2000) and Haga et al. (2002), the first class is the fraction of small-fine woody debris (S-FWD, with $D_{\text {log }}<0.1$ $\mathrm{m}$ and $L_{l o g}<1 \mathrm{~m}$ ), the second to fourth classes are the fraction of large-fine woody debris (L-FWD, featuring $D_{l o g}<0.1 \mathrm{~m}$ and $L_{l o g}>1 \mathrm{~m}$ ) and the fifth and sixth classes are the fraction of large-coarse woody debris (L-CWD, $D_{l o g}>0.1 \mathrm{~m}$ and $L_{l o g}>1 \mathrm{~m}$ ). For each cell of the partitioned catchment, a wood continuity equation is taken for the in- and outflow of wood mass, $Q_{\text {in }}$ and $Q_{\text {out }}$ and the wood volume stored in the cell, $W$.

$$
Q_{\text {in }}(t)-Q_{\text {out }}(t)=\frac{\partial W(t)}{d t}
$$

An equation to link the stored volume and the outflow is chosen as

$$
W(t)=K Q_{\text {out }}(t)
$$

where $K$ is a cell variable, measuring the characteristic response time inside the cell. This is evaluated as follows:

$$
K=\frac{L_{\text {cell }}}{f_{\text {rid }} P_{L_{\text {cell }}^{*}} v_{\text {lim }}}
$$

where $L_{\text {cell }}$ is the length of the cell considered, $f_{\text {rid }}$ is a reduction factor considering the partial wood coverage of the cell and $P_{L_{\text {cell }}^{*}}=1-F_{L_{\text {cell }}^{*}}$ is the probability that a wood piece is not retained in the cell, i.e. it can move out of the cell. The term $F_{L_{c e l l}^{*}}$ is deduced for each cell, according to Eqns. (8) and (9). The term $v_{\text {lim }}$ is the greatest velocity that the wood can achieve rolling inside the cell, calculated depending on the wood and soil properties and on the cell slope and length and, on the water depth and velocity, when overland flow is present (for the importance of the limiting velocity in the wood transport experiment see Bocchiola et al., in press b).

The direct contribution of wood to the channel, $W_{d c}$ i.e. the amount of wood directly falling into the channel during the fire is given for each cell by

$$
\begin{aligned}
& W_{d c}=\left[A_{\text {cell }} \text { DensTree }\right]\left[\frac{D B H^{2} \pi}{4}\left(H_{\text {tree }}-\frac{L_{\text {cell }}}{2}\right)\right] \\
& \mid\left[P_{\text {fall }} C_{\text {comb }} P_{c h}\right]
\end{aligned}
$$

where $A_{\text {cell }}$ is the cell area, DensTree is the tree area density, $\mathrm{DBH}$ is the wood typical diameter at $1.37 \mathrm{~m}$ height, $H_{\text {tree }}$ is the dominating tree height, $P_{\text {fall }}$ is the probability of tree fall, $C_{\text {comb }}$ is the combustion coefficient and $P_{c h}$ is the probability of tree fall towards the channel, calculated as

$$
P_{\text {ch }}=\operatorname{arcos}\left(\frac{H_{\text {tree }}}{2 H_{\text {tree }}}\right)(1+\phi)=\frac{1}{3}(1+\phi)
$$


where $\phi$ is characteristic of the site and depends on the local slope, the dominant wind direction and the main forest aspect (Welty et al., 2002).

An explicit forward finite difference scheme is implemented to resolve the wood mass propagation. A stability condition is evaluated as $L_{c e l l} / \Delta t \geq v_{\text {lim }}$, to find the maximum value of the time step $\Delta t$ for which the solution in convergent; here, it was set $\Delta t=2 \mathrm{~s}$, after a preliminary analysis.

Because the quantity $\phi$ in Eqn. (13) could not be measured directly in the case study area, it has been used here as a tuning parameter of the model. The friction angle at rolling on the hill slopes was deduced from tilt test analysis using soil samples, resulting in $\Phi_{R}=25^{\circ}$; this is slightly dependent on the log diameter (Bocchiola et al., 2006b). However, because of the inherent uncertainty in its estimation and its variability in space, a constant, average value has been used and a sensitivity analysis of the results was carried out. The delivery of wood in dry conditions is calculated immediately after the forest fire, as it is assumed that the DWD moves downhill and soon reaches an equilibrium condition by stopping on a flat cell, leaning against an obstacle, or reaching the channel. The probability of falling, $P_{\text {fall }}$ (Table 2 ) is the number of trees (i.e. a given amount of wood mass) that fall to the ground and provide the initial conditions for the model. Then, according to Eqns.(10), (11) and (12), the wood mass is conveyed towards the channel. For each cell of the partitioned basin, wood mass is stored dynamically and released until equilibrium conditions are reached, when no more wood moves downwards (i.e. the whole amount of wood mass is stored inside some cells).

In dry conditions, the term $K$ in Eqn. (12) is evaluated by taking the probability of escape from the cell $P_{L_{\text {cell }}^{*}}=1-F_{L_{\text {cell }}^{*}}$ as a $L N$ distribution (Eqn. 8), with an average given by Eqn. (9), where the forcing to motion for dry conditions is taken as from Eqn. (6).

Also, the wood module considers the direct wood contribution from those cells close to the channel, as according to Eqn. (13) and Eqn. (14). In wet conditions (i.e. during a storm event) the hydrological model is run and, at each time step, the water depth and velocity, $d_{w}$ and $U_{w}$ are used to calculate the forcing into motion on the hill slopes and into the channel. Accordingly, the term $K$ in Eqn. (12) is evaluated by taking the probability that a wood piece moves outside the cell $P_{L_{\text {cell }}^{*}}=1-F_{L_{\text {cell }}^{*}}$ as a $\mathrm{LN}$ distribution (Eqn. 8), with an average given by Eqn. (9) and a forcing to motion taken from Eqn. (5).

\section{SIMULATION OF WOOD BUDGET}

\section{Dry conditions}

The model is run in dry conditions to simulate the amount of wood mass conveyed to the channel during the 2003 fire event. The initial (i.e. immediately after the fire) spatial distribution of the wood pieces is set according to the sample average spatial density of the wood pieces for each diameter and length class. The wood pieces are then routed according to Eqns. (10), (11) and (12). The module processes each stream tube moving down slope and considers the wood classes independently. If in a cell there is a given amount of wood with given length and diameter and it can move according to the stability condition in Eqn.(6), part of this wood is conveyed towards the next cell (i.e. the closest cell in the stream tube following gravity) as from Eqns. (11) and (12). The amount of wood that is not conveyed down slope, remains in the cell, assuming it has been trapped inside the cell due to the presence of obstacles such as standing trees. Note that this is consistent with Eqns. (11) and (12), stating that the outflow $Q_{\text {out }}$ of wood depends on the wood storage into the cell, $W$ multiplied by $1 / K$ and thus depending on the probability of the wood moving out of the cell $P_{L_{c c l l}^{*}}=1-F_{L_{c e l l}^{*}}$. The wood flow moving out of the cell is routed down slope. As the cells are approached moving down slope, a further amount of wood can be mobilised in each cell. When the channel is reached the module moves to another stream tube. Under dry conditions, the wood module also considers the direct contribution to the channel. This is done according the Eqn.(13). Following Welty et al. (2002), the contributing belt along the river has the same order of magnitude as $H_{\text {trre }}$. Here, the average length of the cells in the stream tubes is in the order of $10 \mathrm{~m}$, while the dominant tree height, $H_{\text {tree }}$ is $13.5 \mathrm{~m}$. Thus, one assumes that only the cells alongside the channel can contribute. The indirect contribution parameter $\phi$ (Eqn. 13) is used as a tuning parameter in the model, by equating the observed amount of wood in the channel from direct contribution (Table 2) with the simulated one. The obtained value is $\phi=0.2$. A sensitivity analysis has been carried out on the results of the model to the value of $\phi$, as shown later.

The procedure stops when the whole basin has been processed and a steady state has been reached where in each cell, including the channel, a given amount of wood is stored. Figure 6 shows the output of the wood budget module in dry conditions, i.e. the distribution of the wood biomass soon after the fire. The friction angle is set therein to its optimal value $\Phi_{R}=28.5^{\circ}$, provided from the sensitivity analysis, shown later. The stream tube partitioning is indicated together with the local slope (blue cells). Notice that the greatest amount of stored wood biomass (dark red) is observed in the flattest cells (light blue), while in the 

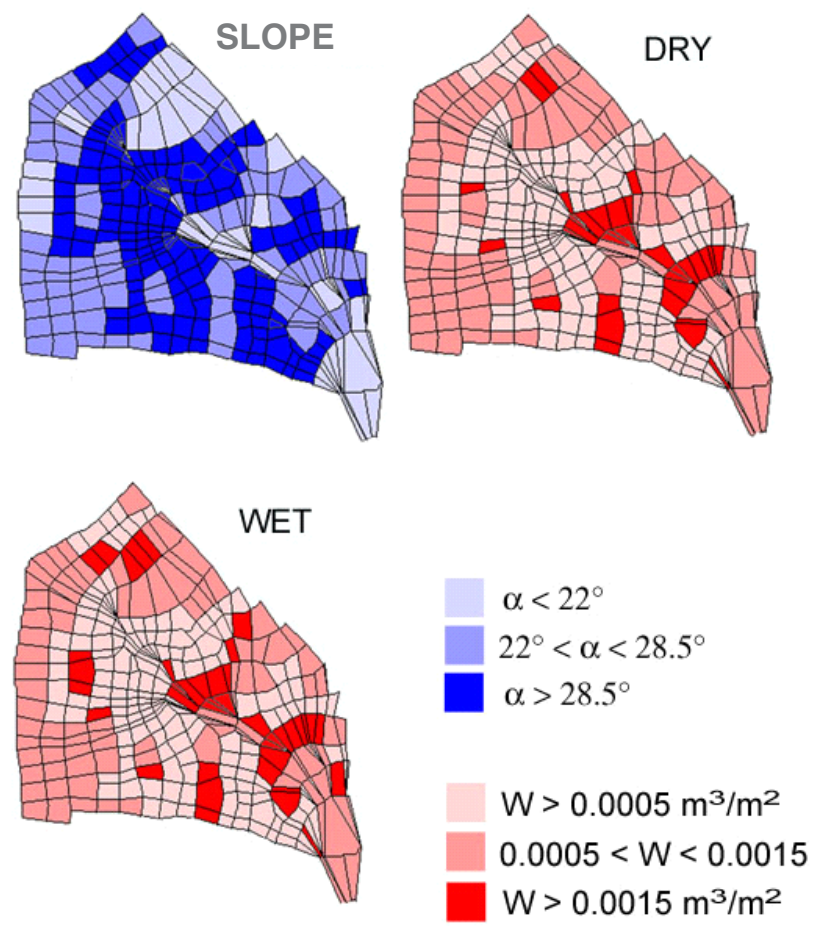

Fig. 6. Model output. Cell slope (blue) and density $\left(\mathrm{m}^{3} / \mathrm{m}^{2}\right)$ of wood debris in dry and wet conditions. $\Phi_{R}=28.5^{\circ}, \phi=0.2$.

steepest cells (dark blue) the wood is swept away by gravity and a smaller amount is observed therein (light red). This is consistent with the idea that the DWD tends to move downward when it falls on a steep slope and to stop when it meets a relatively flat area.

\section{Sensitivity analysis in dry conditions}

A sensitivity analysis of the model's results in dry conditions has been carried out with respect to the average rolling friction angle of the logs $\Phi_{\mathrm{R}}$ of the slope surface, regulating the wood motion. This was tentatively measured in the laboratory from terrain samples, resulting in a value of $\Phi_{\mathrm{R}}=25^{\circ}$. However, it is expected that this value is widely variable, depending on the soil cover in the case study area, such as stones, gravel, pine needles, etc. and on the complex local topography, thus requiring the evaluation of a 'representative' value at the basin scale. First, the optimal value of $\Phi_{R}$ has been found, i.e. that which provides a correct estimation of the amount of woody debris conveyed in channel from motion on the hill slopes, $W_{d}$. This is done by running the model iteratively with increasing values of the friction angle $\Phi_{\mathrm{R}}$ until the model calculated value of $W_{d}$ equals the value deduced from the field survey (Table 2), $W_{d}=W_{c h}-W_{d c}=0.49 \mathrm{~m}^{3}$. The value so obtained is $\Phi_{\mathrm{R}}=28.5^{\circ}$. Figure 7 shows the values of $W_{d}$ calculated by
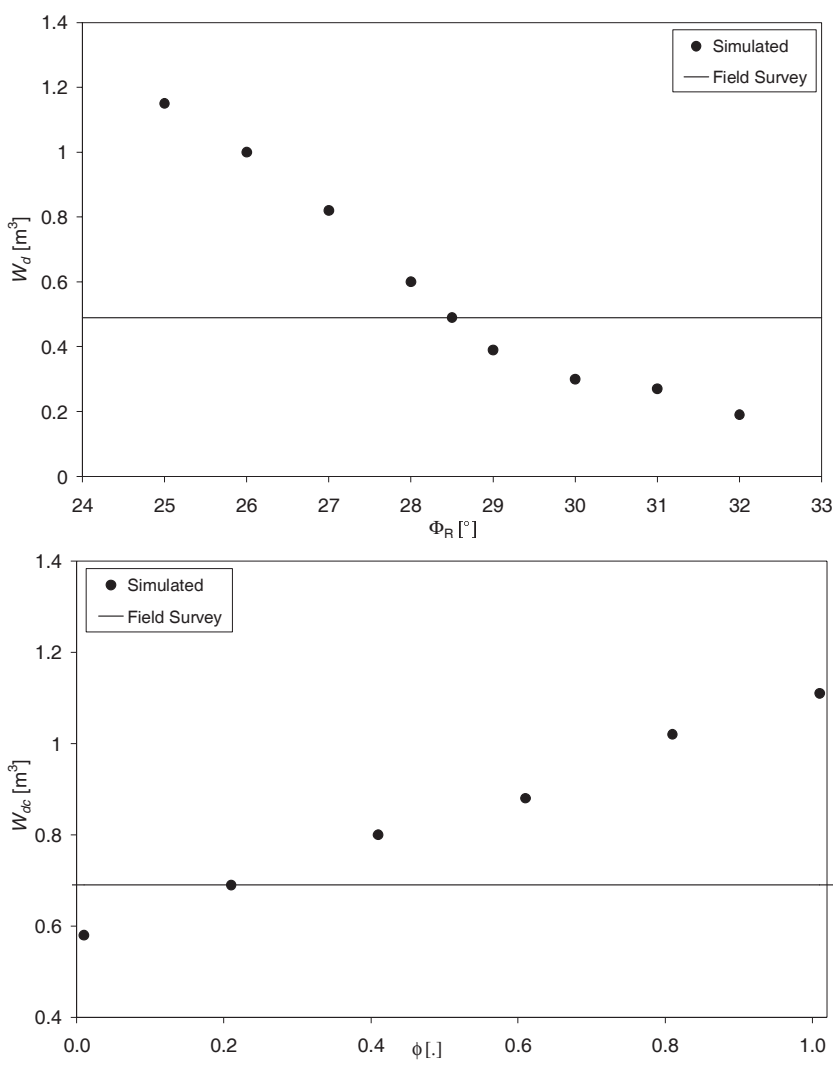

Fig. 7. Sensitivity analysis of the model results. (a) Dry transport: $\Phi_{R^{*}}$ (b) Direct contribution: $\phi$

the wood module, depending on the friction angle. The graph starts from the value $\Phi_{R}=25^{\circ}$, because it was deduced from laboratory experiments and ends with the value $\Phi_{\mathrm{R}}=32^{\circ}$, because it was observed that above such a value a somewhat stable estimation is reached; indeed, the wood module seems sensitive to the friction angle $\Phi_{\mathrm{R}}$. An underestimation of $\Phi_{\mathrm{R}}$ of $3.5^{\circ}$ (i.e. $\Phi_{\mathrm{R}}=25^{\circ}$ in Fig. 7) leads to an estimation of $W_{d}$ $=1.15 \mathrm{~m}^{3}$, almost three times as much as the field value. Similarly, an overestimation of about $4^{\circ}$ (i.e. $\Phi_{\mathrm{R}}=31^{\circ}$ in Fig. 7) leads to $W_{d}=0.2 \mathrm{~m}^{3}$, which is less than half the field value.

This is surely an effect of the steep slopes in the basin considered (see Fig. 6). The value of $\Phi_{R}$ in fact represents a threshold for motion on the hill slopes. For low values of $\Phi_{R}$, the whole basin contributes to the (initiation of) wood transport. For increasing values of $\Phi_{R}$, a smaller and smaller part of the basin contributes, so decreasing the amount of in-channel wood. Also, this effect could be due to the a scale issue because of the small size of the basin, while for bigger areas, the results could be less sensitive to the choice of the representative value of $\Phi_{\mathrm{R}}$. However, the authors will assume henceforth the value of $\Phi_{\mathrm{R}}=28.5$, as it provides a good assessment of $W_{d}$. In Fig. 8, the contribution of wood 
to the channel is given, split into the six diameter classes. Both the volume and the number of pieces of wood is given: those with the smallest diameters contribute greatly in terms of number of pieces but provide a small contribution in terms of wood volume while the largest pieces, although few in number, provide most volume. Figure 9 gives the distribution of the transported woody debris in volume $W_{d}$ inside the channel (divided into 11 steps of $20 \mathrm{~m}$ length moving upstream from the outlet).

A further sensitivity analysis has been carried out with respect to the simulated amount of the direct contribution. This depends on the tree fall direction parameter $\phi$ in Eqn. (13), indicating the expected fall direction of the trees and affecting the direct contribution of wood into the channel. There was no way to assess this parameter directly but it was possible to estimate during the field survey the amount of wood falling directly into the channel (see $W_{d c}$ Table 2). First, the 'optimal' value of $\phi$, i.e. that which matches the simulated to the observed value, is evaluated and results in

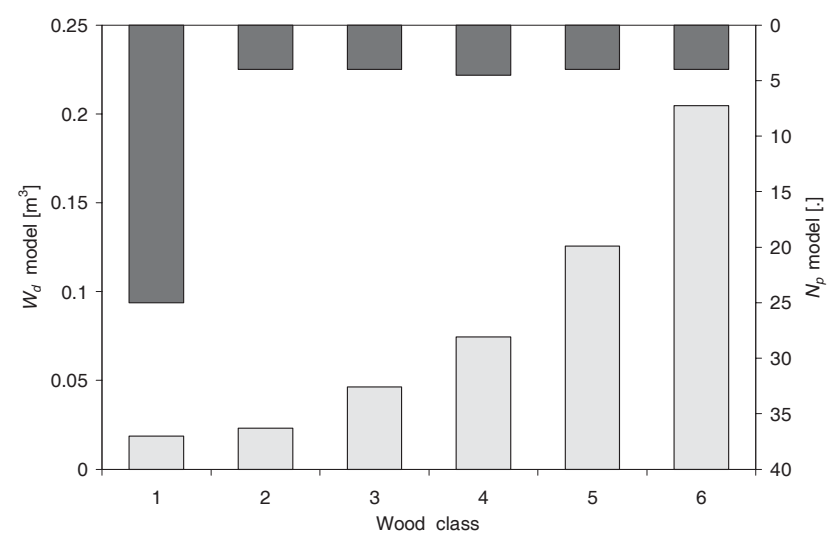

Fig. 8. Model simulated distribution of wood volume transported in dry conditions $\mathrm{W}_{\mathrm{d}}$ in the six wood classes and number of pieces, $\mathrm{N}_{\mathrm{p}}$.



Fig. 9. Model simulated distribution of $\mathrm{W}_{\mathrm{d}}$ and $\mathrm{W}_{\mathrm{dc}}$ along the channel compared with the observed amount of wood $\mathrm{W}_{\mathrm{ch}}$ $\phi=0.2$, as already mentioned. Then, a sensitivity analysis, shown in Fig. 7, is carried out to assess the impact on the model of the uncertainty in the estimation of $\phi$. It seems that the wood model is somewhat less sensitive to the value of $\phi$ than to that of $\Phi_{\mathrm{R}}$. Particularly, by setting $\phi=0.5$, i.e. the suggested reference value (e.g. Welty et al., 2002), the calculated value changes from $W_{d c}=0.69$ to $W_{d c}=0.84$, with an increase of $22 \%$, somewhat more acceptable.

Figure 9 gives the distribution of the direct contribution of wood $W_{d c}$ inside the channel. Therein also, the whole simulated amount of wood $\left(W_{d c}+W_{d}\right)$ is reported, together with the total observed amount of wood in the channel, $W_{c h}$. While the total amount of wood is the same, the distribution of wood in the channel is somewhat different to the observed one.

Note that the model does not provide routing of the wood inside the channel because it is expected that a different approach would be used. This is possibly one reason for the difference in the wood distribution in the channel. Also, the distribution of wood in the model is assumed to be homogeneous and continuous in space, while the actual distribution of the trees is of course discontinuous. This is a further source of error.

\section{Wet conditions}

The wood budget model is then run together with the rainfallrunoff model to simulate the amount of wood mass conveyed to the channel in wet conditions, during the 98-day period following the fire. The stability of the wood module would require a computational time step $\Delta t=2 \mathrm{~s}$. This would increase the required computation time because the rainfall runoff module has been run adopting $\Delta t_{m}=100 \mathrm{~s}$. This issue was solved by feeding the wood module with the output of the runoff module interpolated at the required time resolution. Preliminary analysis showed that this assumption did not provoke any relevant change in the water depth and velocity conditions on the hill slopes. The module is run in wet conditions by using the same parameters of the runoff module as explained before because they provided a good fit of the results in terms of runoff and sediment transport. The same value of $\Phi_{R}=28.5$ was adopted as in the dry conditions, because it is assumed that the friction angle remains constant in the presence of water (e.g. Bocchiola et al., 2006a).

The output of the wet module is given in Fig. 6, i.e. the new distribution of the wood on the hill slopes. Although there is a small difference from the dry conditions, it can be seen that an adjustment of the wood mass occurs in some cells. Particularly, the motion of those pieces of wood that are only just stable under dry conditions (i.e. when the slope of the cell is close to the friction angle) can be triggered by 


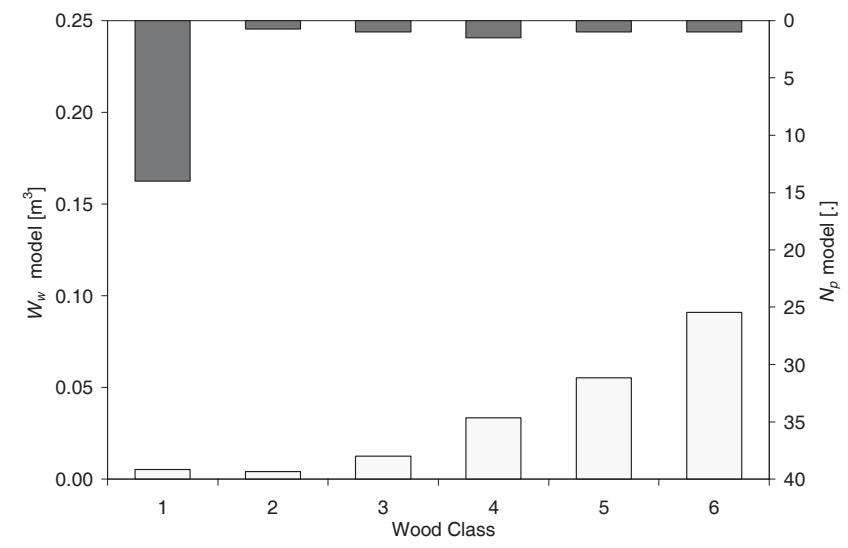

Fig. 10. Model simulated distribution of wood volume transported in wet conditions $W_{w}$ in the six wood classes and number of pieces, $N_{p}$.

the presence of sheet flow, albeit with low depth and velocity. These pieces then stop on flat cells further down the slope.

Figure 10 shows the volume and the number of pieces of wood for the six classes considered. Again, those pieces with the smallest diameters contribute greatest in terms of individual numbers while providing a small contribution in terms of wood volume. Notice also that classes two to six contribute less than two pieces while the first class contributes 14 pieces. This means that one expects to find in the channel a relevant number of S-FWD represented by this class. The final estimated amount of the woody debris volume in wet conditions is $W_{w}=0.202 \mathrm{~m}^{3}$. Figure 11 gives the volume distribution of the woody debris $W_{w}$ inside the channel. In view of the difficulties in mapping the distribution of the Small-Fine Woody Debris (S-FWD), as explained before, it was not possible to compare the results of the model in term of wet wood transport inside the channel. The authors tentatively compare the amount of

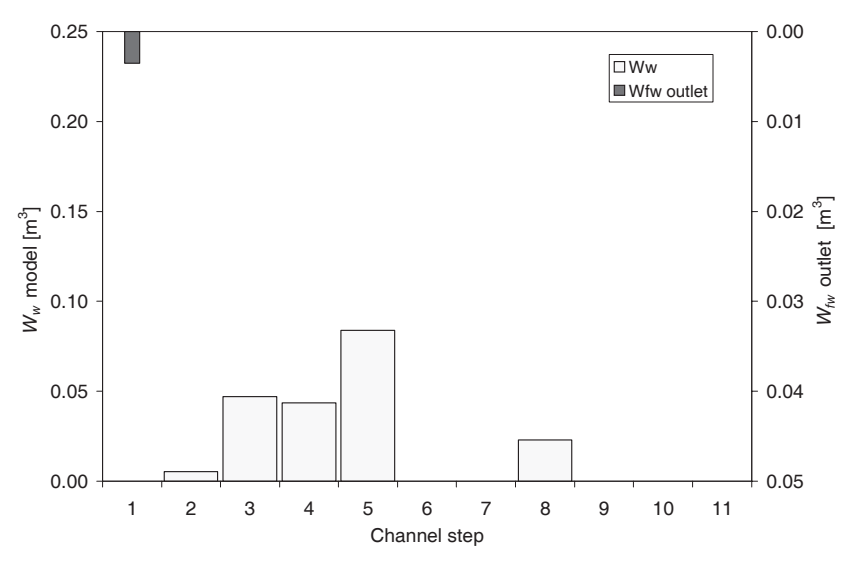

Fig. 11. Model simulated distribution of $\mathrm{W}_{\mathrm{w}}$ along the channel compared with the observed amount of wood from $S-F W D, \mathrm{~W}_{\mathrm{fw}}$ at the channel outlet wood in the first class with the observed value of the wood volume gathered at the weir, $W_{f w}$, composed entirely of SFWD. Although the comparison is not strictly valid, it gives a first indication of the capability of the model to evaluate the transport of wood in wet conditions.

The amount of wood in the first class amounts to $W_{1}=6_{*} 10^{-3} \mathrm{~m}^{3}$ (i.e. 6 litres). The wood volume gathered at the weir amounts to $W_{f w}=3.5 \times 10^{-3} \mathrm{~m}^{3}$ (i.e. 3.5 litres), as in Table 2. This is reasonable, because one assumes that the amount of wood gathered at the channel outlet is a fraction of the total amount of wood conveyed in the channel. Therefore, it seems that the wood module is able to provide to at least an order of magnitude the amount of wood delivered to the channel in wet conditions and considering the finest fraction of the woody debris.

As already explained, it was not possible here to map the motion of any piece of LWD. However, this could be due to the short period considered, as well as to the amount of precipitation observed, not being sufficient to provide a correct wood budget assessment.

Further, the model considers only six classes of wood $\log$ diameter. This provides a somewhat limited capability of description of the wood transport phenomenom, particularly for the smallest diameters (S-FWD, here synthesised with a diameter $D_{\log }=0.03 \mathrm{~m}$ ). This could be a reason, for instance, for the lack of wood in the first channel step, as shown in Fig. 11, contrasting with the presence of wood in the weir. The adoption of smaller diameters could lead to a better description of the dynamics of S-FWD, the most interesting in the wet case.

Eventually, this can be due the uncertainty in assessing the actual precipitation rate on the basin. In fact, the rain gauges considered in the study were outside the basin, thus possibly providing an inadequate representative estimation of rainfall therein. This can lead the model to yield an artificial motion for the wood pieces on the hill slopes, not observed in reality.

\section{Conclusions}

The effect of forest fires is transient but impressive because of the changes in soil hydrology and erosion, accelerated soil degradation and runoff rates. The ultimate effect deals with augmented natural hazards associated with desertification, floods and rapid mass movements. Forest fires have further societal impacts through the loss of soil for agriculture and wildlife and also trigger enhanced urbanisation processes, with a feedback on vulnerability to natural hazard. Accordingly, transient processes after wildfires can modify the landscape substantially. Analysis of transient effects of forest fires can help in addressing 
the counter measures that must be accomplished rapidly under the umbrella of a process knowledge driven approach.

Transient hydrology of river catchments after wildfires involves the merging of experimental investigation, process conceptualisation and mathematical modelling, as well as expertise from hydrology, geology, forestry, agricultural and river engineering, and botany. This paper addresses the complexity of hydrological processes in burned catchments by assessing the mechanisms that control the delivery of runoff, soil sediment and wood debris.

The approach proposed relies on field experiments to support the identification, calibration and validation of a distributed integrated hydrological model describing the processes investigated at the catchment scale; this is of interest for land-use planning and the engineering design of counter measures. The results, albeit preliminary, show that transient complexity after wildfires can be modelled to some extent, and future investigations are worth planning to converge on more and more accurate description of the processes involved. Further, mass movements must be considered explicitly and modelled, including shallow landslides and debris flows. Finally, the interaction of soil instability with wood delivery requires further analysis; this may improve the prospects for predicting landscape shaping due to the occurrence of forest fires.

\section{Acknowledgments}

The authors kindly acknowledge Eng. Silvia Bozzi and Matteo Spada for their valuable help in the experimental campaign and in data retrieval and handling. Also, kind acknowledgments are given to Eng. Davide Motta, Alessandro Greppi and Chiara Narciso, for their contribution to the development of the model in partial fulfilment of their Master's Thesis. Funding for the present research was granted by the Liguria Region through the INTERREG 3B DESERNET Project, by the National Institute for Mountain Research, INRM and by the EU through project IRASMOS (EC Contract 018412).

\section{References}

Abbe, T.B. and Montgomery, D.R., 1996. Large woody debris jams, channel hydraulics and habitat formation in large rivers. Regul. River., 12, 201-221.

Andrus, C.W., Long, B.A. and Froehlich, H.A., 1988. Woody debris and its contribution to pool formation in a costal stream 50 years after logging. Can. J. Fisheries Aquat. Manage., 45, 2080-2086.

Benda, L.E. and Sias, J.C., 2003. A quantitative framework for evaluating the mass balance of in stream organic debris. Forest Ecol. Manage., 172, 1-16.
Bocchiola, D., Catalano, F., Menduni, G. and Passoni, G., 2002. An analytical-numerical approach to the hydraulics of floating debris in river channels. J. Hydrol., 269, 65-78.

Bocchiola, D., Rulli, M.C. and Rosso, R., 2004. Woody debris dynamics in fire-floods environment. Proc. 6th Int. Conf. on Hydroscience and Engineering (ICHE-2004), Brisbane, Australia. 165.

Bocchiola, D., Rulli, M.C. and Rosso, R., 2006a. Flume experiments on wood entrainment in rivers, Adv. Water Res., 29, 1182-1195.

Bocchiola, D., Rulli, M.C. and Rosso, R., 2006b. Transport of Large Woody Debris in the presence of obstacles. Geomorphology, 76, 166-178.

Booker, F.A., 1998. Landscape and management response to wildfires in California. Masters Thesis, Berkeley, University of California, USA.

Braudrick, C.A. and Grant, G.E., 2000. When do logs move in rivers? Water Resour. Res., 36, 571-583.

Braudrick, C.A. and Grant, G.E., 2001. Transport and deposition of large woody debris in streams: a flume experiment. Geomorphology, 41, 263-283.

Clapp, R.B. and Hornberger, G.M., 1978. Empirical equations for some hydraulic properties. Water Resour. Res., 14, 601-604.

Conedera, M., Peter, L., Marxer, P., Forster, F., Rickenmann, D. and Re, L., 2003. Consequences of forest fires on the hydrogeological response of mountain catchments: a case study of the Riale Buffaga, Ticino, Switzerland. Earth Surf. Process. Landf., 28, 117-129.

DeBano, L.F., 2000. The role of fire and soil heating on water repellency in wildland environments: a review. J. Hydrol., 231232, 195-206.

Dekker, L.W. and Ritsema, C.J., 1994. How water moves in a water repellent sandy soil -1 . Potential and actual water repellency. Water Resour. Res., 30, 2507-2517.

Fetherston, K.L., Naiman, R.J. and Bilby, R.E., 1995. Large woody debris, physical process and riparian forest development in montane river networks of the Pacific Northwest. Geomorphology, 13, 133-144.

Foster, G. R., 1982. Modeling the erosion process. In: Hydrologic Modeling of Small Watersheds, C.T. Haan, H.P. Johnson and D.L. Brakensiek (Eds.). Amer. Soc. of Agric. Eng., St. Joseph, Minn. USA.

Gomi, T., Sidle, R.C., Woodsmith, R.D. and Bryant, M.D., 2003. Characteristics of channel steps and reach morphology in headwater streams southeast Alaska. Geomorphology, 51, 225242.

Gurnell, A.M., Petts, G.E., Harris, N., Ward, J.V., Tockner, K., Edwards, P.J. and Kollman, J., 2000. Large Wood retention in river channels: the case of the Fiume Tagliamento, Italy. Earth Surf. Process. Landf., 25, 255-275.

Haga, H., Kumagai, T., Otsuki, K. and Ogawa, S., 2002. Transport and retention of coarse woody debris in mountain streams: An in situ field experiment of log transport and a field survey of coarse woody debris distribution. Water Resour. Res., 38, 10291044.

Hygelund, B. and Manga, M., 2003. Field measurement of drag coefficients for model large woody debris. Geomorphology, $\mathbf{5 1 , 1 7 5 - 1 8 5 . ~}$

Jackson, C.R. and Sturm, C.A., 2002. Woody debris and channel morphology in first and second order forested channels in Washington's coast ranges. Water Resour. Res., 38, 16-1,16-14.

Johansen, P.J., Hakonson, T.E. and Breshears, D.D., 2001. Post fire runoff and erosion from rainfall simulation: contrasting forests with shrub lands and grasslands. Hydrol. Process., 15, 2953-2965. 
Keller, E.A. and Swanson, F.J., 1979. Effects of large organic material on channel form and fluvial processes. Earth Surf. Process. Landf., 4, 361-380.

Lancaster, S.T., Hayes, S.K. and Grant, G.E., 2003. Effects of wood on debris flow runout in small mountain watersheds. Water Resour. Res., 39, 4-1, 4-21.

Letey, J., 2001. Causes and consequences of fire-induced soil water repellence. Hydrol. Process., 15, 2867-2875.

Lienkaemper, G.W. and Swanson, F., 1987. Dynamics of large woody debris in streams of in old growth Douglas-fir forests. Can. J. Forest Res., 17, 150-156.

Manga, M. and Kirchner, J. W., 2000. Stress Partitioning in streams by large woody debris. Water Resour. Res., 36, 2373-2379.

Margaris, N.S., 1980. Structure and dynamics of Mediterranean type vegetation. Portugaliae Acta Biol., 16, 45-48.

Menduni, G., Pagani, A., Rulli, M. C. and Rosso, R., 2002. A nonconventional watershed partitioning method for semi-distributed hydrological modelling: the package Aladhyn. Hydrol. Process., 16, 277-291.

Murgatroyd, A.L. and Ternan, J.L., 1983. The impact of afforestation on stream bank erosion and channel form. Earth Surf. Process. Landf., 8, 357-369.

Naveh, Z., 1975. The evolutionary significance of fire in the Mediterranean region. Vegetatio, 29, 199-208.

Onstad, C.A. and Brakensiek, D.L., 1968. Watershed simulation by stream path analogy. Water Resour. Res., 4, 965-971.

Panini, T., Salvador Sanchis, M.P. and Torri, D., 1993. A portable rain simulator for rough and smooth morphologies. Quaderni di scienza del suolo, Vol. 5. In Italian.

Prosser, I. and Williams, L., 1997. The impact of wildfire on runoff and erosion in native Eucalyptus forest. Hydrol. Process., 12, 251-265.

Robichaud, P.R. and Hungerford, R.D., 2000. Water repellence by laboratory burning of four northern Rocky Mountain forest soils. J. Hydrol., 231-232, 207-219.

Rosso, R., Rulli, M.C. and Vannucchi, G., 2005. A physically based model for the hydrologic control on shallow landsliding. Water Resour. Res., 2005WR004369R.
Rulli, M.C. and Rosso, R., 2005. Modeling catchment erosion after wildfires in the San Gabriel Mountains of southern California. Geophys. Res. Lett., 32, L19401, doi:10.1029/ 2005GL023635.

Rulli, M.C., Bozzi, S., Spada, M., Bocchiola, D. and Rosso, R., 2006. Rainfall simulations on a fire disturbed mediterranean area. J. Hydrol., 327, 323-338.

Rulli, M. C., Spada, M., Bozzi, S., Bocchiola, D. and Rosso, R., 2005. Modelling sediment yield in burned areas, IAHS Publications, Scientific Assembly VII, Foz do Iguacu, April 2005. 2, 162-170.

Shields, D.F. and Gippel, C.J., 1995. Prediction of effects of woody debris removal on flow resistance. J. Hydraul. Eng.-ASCE. 121, 341-354.

Sun, H., Cornish, P.S. and Daniell, T.M., 2002. Contour-based digital elevation modeling of watershed erosion and sedimentation: Erosion and sedimentation estimation tool (EROSET). Water Resour. Res., 38, 1233.

Vertessy, R. A. and Eisenbeer, H., 1999. Distributed modelling of storm generation in an Amazonian rain forest catchment: effects of model parameterization. Water Resour. Res., 35, 2173-2187.

Welty, J.J., Beechie, T., Sullivan, K., Hyink, D.M., Bilby, R.E., Andrus, C. and Pess, G., 2002. Riparian aquatic interaction simulator (RAIS): a model of riparian forest dynamics for the generation of large woody debris and shade. Forest Ecol. Manage., 162, 299-318.

Wilson, C.J., 1999. Effects of logging and fire on runoff and erosion on highly erodible granitic soils in Tasmania. Water Resour. Res., 35, 3531-3546.

Wischmeier, W.H. and Smith, D.D., 1978. Predicting rainfall erosion losses - A guide to conservation planning. Agricultural Handbook 537, USDA.

Zierholz, C., 1997. The effects of fire on runoff and soil erosion in Royal National Park, New South Wales. Masters Thesis, Australian National University, Canberra, Australia. 126 pp. 